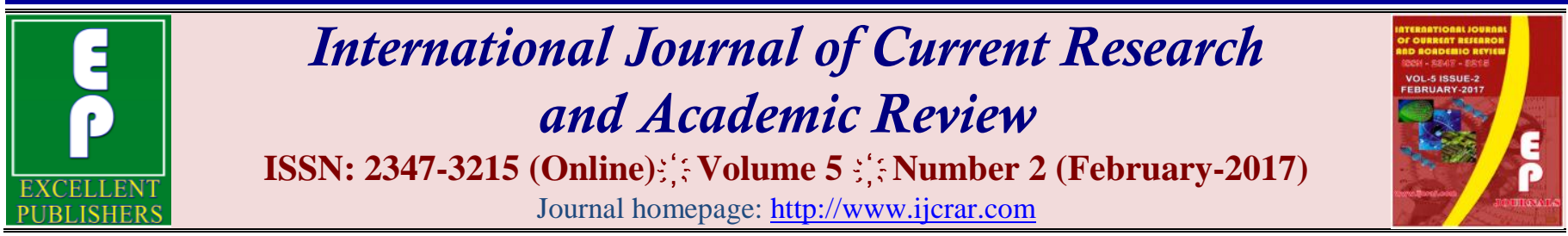

doi: http://dx.doi.org/10.20546/ijcrar.2017.502.009

\title{
Solar Distillation an Advance Treatment for Decontamination of River Water
}

\author{
Anuradha Awasthi, Bhawana Pathak and M.H. Fulekar* \\ School of Environment and Sustainable Development, Central University of Gujarat, Gandhinagar, 382030 Gujarat, \\ India
}

*Corresponding author

\begin{abstract}
River water Sabarmati is contaminated from the various sources viz industrial waste, domestic waste and other sources. River water is characterized for physico-chemical parameters at different location along the side of Gandhinagar- Ahmadabad and found unsuitable for drinking purposes unless treated by advance treatment technology. The Solar distillation unit developed and modified with three inbuilt basins system has been used for treatment of Sabarmati river water. The first step involved in the treatment of river water is to vaporize the water based on solar radiation allowed to interact with the three basins of solar distillation unit during vaporization and condensation. The rate of water, which is coming from the inlet tank, was measured and vaporized, condensed water was collected, after each hour during morning to evening (8:00am to 6:00pm).The data indicates the physico-chemical characteristics of river water existing at different location and physico-chemical characteristics of river water; after solar distillation treatment. Parameter such as $\mathrm{pH}$, Turbidity, Ammonia, Nitrate, nitrite, sulphate, BOD and COD were found reduced due to deposition of contaminants by solar distillation process. The river water after solar distillation was found complied with the standard for intended use. Thus, the present solar based distillation unit, under solar radiation treatment via vaporization, condensation was found effective and efficient for treatment of river water.
\end{abstract}

\section{Article Info}

Accepted: 25 January 2017

Available Online: 20 February 2017

\section{Keywords}

Sabarmati river water, solar distillation, Subhash Bridge, Solar radiation etc.

\section{Introduction}

Global society in the 21 st century is facing challenges of improving the quality of air, water, soil environment and maintaining the ecological balance. Environmental pollution has become a major global concern (Fulekar et al., 2014).Increasing numbers of industries, besides production are responsible for rising environmental problems. (Olaniram, 1995). As per notations, given by world health organization (WHO), less than $1 / 6$ of the world's population have not assessedpure or potable drinking water (European Public Health Alliance, 2009). Water pollution destroy the nature by two way,negative effects on living organisms either by impact on environment directly and indirectly that damage the human well being and causes the harmful effects to the community(Carter, 1985). The water pollution is hazardous for both the aquatic life and human health (Hugh and Madoka, 2005), so it is necessary that water quality of river meet the standards. Quality of Water is important for the human health and environment (Turner et al., 1998). River water is the key source of fresh water. 
Most of the Indian cities are facing moderate to high level of water shortage, this due to rapid increase in number of industries, agriculture advancement and urbanization. Industrialization is the main reason for water scarcity. River water is the main source of water. Sabarmati River is famous river in Gujarat state. It originates in the Aravali range of the Udaipur (Rajasthan) from Dhebar Lake and after travelling 371 $\mathrm{km}$ it meets with Gulf of Combay of Arabian Sea. Sabarmati River's basin size is around $105 \mathrm{~km}$ in width and $300 \mathrm{~km}$ in length. The Sabarmati river catchment area which is divided into two, its total catchment area is around 21,674 Sq km, Out of which 18850 sq.km lies in Gujarat state and remaining 4124 sq.km in Rajasthan. It originates from Aravali hills at north latitude of $24^{\circ} 40$ and in east longitude of $73^{\circ} 20^{\prime}$ at the elevation of 762 meters close to the well-liked shrine of Amba Bhavani in the Rajasthan (Gandhi, 2013). Major polluting substances receiving to river from different industries so may cause damage the water quality. One of the major causes of contaminants is discharged of effluent either treated or untreated domestic wastes etc.

The present research work deals with the treatment of river water using designed and developed solar distillation unit. The mechanism involve the trapping of solar radiation for vaporization of inlet water which undergo treatment through three inbuilt basin inside solar system and further vaporized water, after interaction result into condensation. During the period of vaporization interaction and condensation the contaminated water deposit the solids and remove the contaminant. This has developed advance treatment of river water meeting the standards prescribed for water quality. Treatment of contaminated river water by solar distillation is a safe and suitable way for water purification (Sobha et al., 2012).It is an eco-friendly and low cost technology for water treatment (Panchal, 2015).

\section{Materials and Methods}

Sabarmati River, located as Gandhinagar- Ahmadabad has been selected for the present study. Sabarmati river water collected from Subhash Bridge near Ahmadabad from three different locations. The water sample was analyzed using APHA standard, 2012. The parameters analyzed included (pH, EC, salinity, turbidity, alkalinity, hardness, chloride, sulphate, ammonia, nitrate, nitrite, phosphorous, carbonate, bicarbonate, calcium, magnesium, sodium, COB and BOD). The solar distillation unit generally used for heating the water by vaporization under the influence of solar radiation and supplied as potable water. The unit has been modified with three basins system inbuilt inside the solar distillation unit so that vaporization of water occur in three basins at 1 stage, 2 stage and 3 stage for interaction at three stages and help for the decontaminating the water. Solar system with three basins has been used to vaporized, condensed water, after interaction water was collected at bottom; treated water was characterized for ensuring decontamination.

\section{Experimental procedure}

* At the beginning of the experiment, River water is filled in the storage tank after that basin is filled up to $3 \mathrm{~cm}$ of height on night time through the inlet pipe which is direct connect with the upper basin.

* The glass, which covers the upper basin, is cleaned daily in the morning for removal of extra dust and particles which is deposited on the upper surface of glass before stating the setup.

* The experiment setup was set in the November month from 10 to 24 November 2015 for river water.

* The reading was recorded and taken from morning 9 am to evening $6 \mathrm{pm}$ at hourly intervals.

\section{Results and Discussion}

Sabarmati River water studied for decontamination of the water to comply with the standards for potable water as per the WHO. The following parameters have been characterized from the different location of the Sabarmati River from Gandhinagar to Ahmadabad, Gujarat. The solar distillation unit developed and modified with three inbuilt basin has been used for treatment of river water through the process of vaporization, interaction with three inbuilt basins condensation. The treated water again characterized to ensure compliance with standard as to use water for intended use (Table 3).

The data analyzed for water quality of Sabarmati River water shows that most of the parameter (TDS, Alkalinity, Hardness, Chloride, EC, calcium, magnesium and Sodium) were under the permissible limits according to the BIS and WHO permissible limits. However the $\mathrm{pH}$, turbidity, BOD, COD, ammonia, nitrate, nitrite, phosphate, sulphate were present in high concentration. The treatment of river water through solar distillation unit has brought to the level prescribed for water quality 
similarly, the studied done by Usharani et al., 2010 physic-chemical analysis of river (Noyyal in perur).

The water parameters were assessed and their values brought, after treatment, compliance with the standards

\section{pH}

Optimal $\mathrm{pH}$ range for sustainable aquatic life is $\mathrm{pH}$ 6.58.5. The $\mathrm{pH}$ was found ranging from 7.38 to 7.80 with an average value 7.52 before the solar distillation (Table 1). The reduction in the concentration of $\mathrm{pH}$ after the solar distillation was not much because the water sample was collected in the pre monsoon season and the concentration of bicarbonates from $127.92 \mathrm{mg} / \mathrm{l}$ to 34.25 $\mathrm{mg} / \mathrm{l}$ and carbonates was found $12.38 \mathrm{mg} / \mathrm{l}$ and after the solar distillation its reduced to some extent $10.01 \mathrm{mg} / \mathrm{l}$ may be due to slight change in the value of $\mathrm{pH}$ because carbonates and bicarbonates is the principal component which regulate the $\mathrm{pH}$ in natural waters (APHA, 2012). The study was carried out by the Raju and Narayana (2015) and Siddiqqui et al., (2015) shows the value the $\mathrm{pH}$ was found 7.46 after the solar distillation.

\section{Electrical conductivity}

EC represents the dissolved salt present in river water. The concentration of EC was not reported high in water sample. The EC was found 1.75 before the treatment ranging value $1.32(\mu \mathrm{S} / \mathrm{cm})$ to $2.29(\mu \mathrm{S} / \mathrm{cm})$. After the solar distillation the slight change occurred in value of EC. It showed that solar distillation has an effectiveness of reducing the dissolved salt. The studied EC reduction was also carried out by (Siddiqqui et al., 2015) using different water treatment methods.

\section{Alkalinity}

Alkalinity is the primarily way of measuring the acid neutralizing the capacity of water.Alkalinity of river water shows within the permissible limit according to(WHO) i.e. ranging from $179.46 \mathrm{mg} / \mathrm{l}$ to $180.30 \mathrm{mg} / \mathrm{l}$ with an average value $179.77 \mathrm{mg} / \mathrm{l}$. After the solar distillation insignificant change occurred in the value of alkalinity and found $169.26 \mathrm{mg} / \mathrm{l}$. The alkalinity indicates the conductivity of cations and anions. Alkalinity is less due to the high turbidity of water sample.

\section{Hardness (Calcium and Magnesium)}

Hardness of water is not a specific constituent but is a variable and complex mixture of cations and anions.
Hardness was present in river water with the average value $115.25 \mathrm{mg} / \mathrm{l}$ presented in table 1 . It was reduced from $4.01 \mathrm{mg} / \mathrm{l}$ after the solar distillation with an average value $3.90 \mathrm{mg} / \mathrm{l}$ to $4.09 \mathrm{mg} / \mathrm{l}$. The concentration of hardness was not much higher slight change was occurred after the solar distillation may be due to presence of enough concentration of calcium and magnesium.

Calcium and magnesium dissolved in water are the two most common minerals that make water hard. The value of magnesium in river water sample was found in the range of $7.93 \mathrm{mg} / \mathrm{l}$ to $9.89 \mathrm{mg} / \mathrm{l}$ with an average value $8.65 \mathrm{mg} / \mathrm{l}$ where as the concentration of calcium was found $12.38 \mathrm{mg} / \mathrm{l}$ before the solar distillation unit, after the solar treatment the not much variability was happened in the values of magnesium and calcium. Magnesium value reduced $2.69 \mathrm{mg} / \mathrm{l}$ and calcium concentration was found $3.11 \mathrm{mg} / \mathrm{l}$ (Table 2). These values of magnesium and calcium is required and prescribed value for potable water according to WHO.

\section{Carbonates and bicarbonates}

Carbonates and bicarbonates indicate the presence of cation and anions and their conductivity and presence in water. The value of carbonates and bicarbonates in Sabarmati river water was found under the control level (Table 3). Carbonate was found $12.38 \mathrm{mg} / \mathrm{l}$ and bicarbonate was found $127.92 \mathrm{mg} / \mathrm{l}$ before the solar distillation process (Table 1). The value slightly reduced after the solar distillation and condensation, carbonates shows $10.01 \mathrm{mg} / \mathrm{l}$ and bicarbonates shows $34.25 \mathrm{mg} / \mathrm{l}$. This value of carbonate and bicarbonate was suitable for potable water use according WHO (Table 3).

\section{Chloride}

The chloride of river water indicates the presence of salt and minerals. Chloride content was found in average value in river water sample was found $28.11 \mathrm{mg} / \mathrm{l}$. After the solar distillation vaporization and condensation treatment chloride content reduced to $20.06 \mathrm{mg} / \mathrm{l}$ because during the vaporization and condensation process dissociation of mineral was occurred and the salt content deposit on the basin surface.

\section{Sulphate}

Sulphate of river water was found with an average value $448.1 \mathrm{mg} / \mathrm{l}$ which was above the permissible limit according to water standard prescribed by WHO. 
The presence of higher concentration of sulphate indicates the presence of organic and chemical contaminate due to the discharge of industrial wastes in river water. After the solar distillation process the concentration of sulphate was reduced and found 351.77 $\mathrm{mg} / \mathrm{lbecause}$ in the vaporization and condensation process in solar distillation process the organic and inorganic contaminant deposited under the influence of high heat.

\section{Biological parameters}

The biological parameters studied to check the availability of biological activity and nutrients availability in river water. Ammonia, nitrite and nitrate were studied in the Sabarmati river water. The biological parameters was found in higher concentration because of the discharge of industries and organic contamination. The initial value of Ammonia was ranging from 1.40 $\mathrm{mg} / \mathrm{l}$ to $1.59 \mathrm{mg} / \mathrm{l}$, nitrate was ranging from $51.00 \mathrm{mg} / \mathrm{l}$ to $54.46 \mathrm{mg} / \mathrm{l}$, nitrite was ranging from $0.38 \mathrm{mg} / \mathrm{l}$ to 0.47 $\mathrm{mg} / \mathrm{l}$ (Table 1). After the solar distillation the concentration of ammonia was reduced from with an average value from $0.36 \mathrm{mg} / \mathrm{l}$, Nitrate average value was found $38.50 \mathrm{mg} / \mathrm{l}$, nitrite with an average value $0.25 \mathrm{mg} / \mathrm{l}$ (Table 2) and comply with the prescribed water standards by WHO (Table 3) Because of the sterilization of microbial activity at a certain temperature which was developed in the inbuilt three basins shows that solar distillation was an effective and efficient treatment for river water decontamination.

Table.1 Physico-chemical characterization of Sabarmati River water before and after comply with water standards

\begin{tabular}{lclll}
\hline S.No & Parameters & Before & After & $\begin{array}{l}\text { Comply with } \\
\text { Standards }\end{array}$ \\
\hline $\mathbf{1}$ & $\mathbf{p H}$ & 7.52 & 7.46 & $\mathbf{6 . 5}-\mathbf{8 . 5}$ \\
$\mathbf{2}$ & $\mathbf{E C}(\boldsymbol{\mu S} / \mathrm{cm})$ & 1.75 & 0.24 & $\mathbf{1 5 0 0}$ (by WHO) \\
$\mathbf{3}$ & Turbidity (NTU) & 27.12 & 3.78 & $\mathbf{1 - 5}$ \\
$\mathbf{4}$ & Alkalinity (mg/L) & 179.77 & 169.26 & $\mathbf{2 0 0 - 6 0 0}$ \\
$\mathbf{5}$ & Hardness (mg/L) & 115.25 & 4.01 & $\mathbf{3 0 0 - 6 0 0}$ \\
$\mathbf{6}$ & Chloride (mg/L) & 28.11 & 20.06 & $\mathbf{2 5 0 - 1 0 0 0}$ \\
$\mathbf{7}$ & Sulphate (mg/L) & 448.1 & 351.77 & $\mathbf{2 0 0 - 4 0 0}$ \\
$\mathbf{8}$ & Ammonia (mg/L) & 1.50 & 0.36 & $\mathbf{0 . 5}$ \\
$\mathbf{9}$ & Nitrate (mg/L) & 53.01 & 38.50 & $\mathbf{4 5}$ \\
$\mathbf{1 0}$ & Nitrite (mg/L) & 0.42 & 0.25 & $\mathbf{0 . 3}$ \\
$\mathbf{1 1}$ & Phosphorus (mg/L) & 1.63 & 0.57 & $\mathbf{1 . 0}$ (by WHO) \\
$\mathbf{1 2}$ & Calcium (mg/L) & 11.33 & 3.11 & $\mathbf{7 5}$ \\
$\mathbf{1 3}$ & Magnesium (mg/L) & 8.65 & 2.69 & $\mathbf{3 0}$ \\
\hline $\mathbf{1 4}$ & Sodium (mg/L) & 20.42 & 2.99 & $\mathbf{2 0 0}$ (by WHO) \\
$\mathbf{1 5}$ & BOD (mg/L) & 6.39 & 3.87 & $\mathbf{5}$ \\
\hline $\mathbf{1 6}$ & COD (mg/L) & 17.04 & 8.42 & $\mathbf{1 0}$ \\
$\mathbf{1 7}$ & Carbonate (mg/L) & 12.38 & 10.01 & $\mathbf{2 0 0 - 6 0 0}$ \\
$\mathbf{1 8}$ & Bicarbonate (mg/L) & 127.92 & 34.25 & $\mathbf{3 0 0}$ \\
\hline & & & &
\end{tabular}


Int.J.Curr.Res.Aca.Rev.2017; 5(2): 63-70

Table.2 Physico-chemical characterization of Sabarmati River water before the solar distillation

\begin{tabular}{|c|c|c|c|c|c|c|c|c|c|c|c|c|c|c|}
\hline S. & Parameters & & & & & Site 2 & & & & & & 3 & & Total \\
\hline & & 1 & 2 & 3 & AV & 1 & 2 & 3 & $\mathbf{A V}$ & 1 & 2 & 3 & AV & $\begin{array}{c}\text { Before } \\
\text { SD }\end{array}$ \\
\hline 1 & pH & 7.45 & 7.30 & 7.40 & 7.38 & 7.20 & 7.10 & 8.00 & 7.40 & 7.90 & 7.80 & 7.70 & 7.80 & 7.52 \\
\hline 2 & $\mathrm{EC}(\mu \mathrm{S} / \mathrm{cm})$ & 2.40 & 2.50 & 1.98 & 2.29 & 1.50 & 1.70 & 1.80 & 1.66 & 1.20 & 1.40 & 1.38 & 1.32 & 1.75 \\
\hline 3 & $\begin{array}{c}\text { Turbidity } \\
\text { (NTU) }\end{array}$ & 25.95 & 24.90 & 25.65 & 25.50 & 26.040 & 26.50 & 26.10 & 26.33 & 29.50 & 29.10 & 30.0 & 29.53 & 27.12 \\
\hline 4 & $\begin{array}{c}\text { Alkalinity } \\
(\mathbf{m g} / \mathbf{L})\end{array}$ & 178.80 & 179.00 & 179.40 & 179.40 & 180.70 & 180.40 & 180.30 & 180.46 & 180.00 & 179.50 & 178.90 & 179.46 & 179.77 \\
\hline 5 & $\begin{array}{c}\text { Hardness } \\
(\mathrm{mg} / \mathrm{L})\end{array}$ & 118 & 116 & 119 & 117 & 114.80 & 115.30 & 115.10 & 115.06 & 113.70 & 113.80 & 113.60 & 113.70 & 115.25 \\
\hline 6 & $\begin{array}{l}\text { Chloride } \\
\text { (mg/L) }\end{array}$ & 30.98 & 30.90 & 30.82 & 30.90 & 27.60 & 27.50 & 28.10 & 27.70 & 25.90 & 26.80 & 26.95 & 26.55 & 28.11 \\
\hline 7 & $\begin{array}{c}\text { Sulphate } \\
(\mathrm{mg} / \mathrm{L})\end{array}$ & 420 & 450 & 440 & 436 & 440 & 460 & 465 & 445 & 470 & 480 & 440 & 463.33 & 448.1 \\
\hline 8 & $\begin{array}{c}\text { Ammonia } \\
(\mathrm{mg} / \mathrm{L})\end{array}$ & 1.60 & 1.70 & 1.40 & 1.56 & 1.50 & 1.60 & 1.69 & 1.59 & 1.28 & 1.39 & 1.40 & 1.35 & 1.50 \\
\hline 9 & Nitrate $(\mathbf{m g} / \mathbf{L})$ & 48 & 52 & 53 & 51 & 54 & 53.38 & 53.40 & 53.59 & 55 & 53.80 & 54.60 & 54.46 & 53.01 \\
\hline 10 & Nitrite (mg/L) & 0.45 & 0.48 & 0.50 & 0.47 & 0.40 & 0.410 & 0.38 & 0.39 & 0.45 & 0.42 & 0.35 & 0.40 & 0.42 \\
\hline 11 & $\begin{array}{c}\text { Phosphorus } \\
(\mathrm{mg} / \mathrm{L})\end{array}$ & 1.45 & 1.48 & 1.50 & 1.547 & 1.70 & 1.72 & 1.60 & 1.67 & 1.72 & 1.68 & 1.70 & 1.70 & 1.63 \\
\hline 12 & Calcium (mg/L) & 10.50 & 10.40 & 10.60 & 10.50 & 11.20 & 11.60 & 11.70 & 11.50 & 12.20 & 12.55 & 12.50 & 12.00 & 11.33 \\
\hline 13 & $\begin{array}{c}\text { Magnesium } \\
(\mathrm{mg} / \mathrm{L})\end{array}$ & 9.82 & 9.90 & 9.95 & 9.89 & 8.10 & 8.00 & 8.30 & 8.13 & 7.85 & 7.95 & 8.00 & 7.93 & 8.65 \\
\hline 14 & Sodium (mg/L) & 22 & 21.65 & 22.20 & 21.9 & 18.50 & 18.60 & 18.40 & 18.50 & 20.90 & 21.00 & 20.70 & 20.86 & 20.42 \\
\hline 15 & $\begin{array}{c}\text { Carbonate } \\
(\mathrm{mg} / \mathrm{L})\end{array}$ & 10.70 & 11.20 & 11.30 & 11.06 & 12.89 & 13.20 & 13.40 & 13.16 & 13.00 & 12.98 & 12.80 & 12.92 & 12.38 \\
\hline 16 & $\begin{array}{l}\text { Bicarbonate } \\
(\mathrm{mg} / \mathrm{L})\end{array}$ & 130 & 127 & 131 & 129.33 & 128.00 & 127.20 & 127.10 & 127.43 & 126.98 & 126.80 & 127.30 & 127.02 & 127.92 \\
\hline 17 & BOD (mg/L) & 6.50 & 6.20 & 6.10 & 6.26 & 6.44 & 6.24 & 6.37 & 6.35 & 6.40 & 6.70 & 6.60 & 6.56 & 6.39 \\
\hline 18 & COD (mg/L) & 15.00 & 15.20 & 15.40 & 15.20 & 15.40 & 15.60 & 15.70 & 15.56 & 21.00 & 20.40 & 20.30 & 20.56 & 17.04 \\
\hline
\end{tabular}


Int.J.Curr.Res.Aca.Rev.2017; 5(2): 63-70

Table.3 Physico-chemical characterization of Sabarmati River water after the solar distillation

\begin{tabular}{|c|c|c|c|c|c|c|c|c|c|c|c|c|c|c|}
\hline \multirow{2}{*}{$\begin{array}{l}\text { Sn } \\
\text { No }\end{array}$} & \multirow[t]{2}{*}{ Parameters name } & \multicolumn{4}{|c|}{ Site 1} & \multicolumn{4}{|l|}{ Site 2} & \multicolumn{4}{|c|}{ Site 3} & \multirow{2}{*}{$\begin{array}{c}\text { AV } \\
\text { After } \\
\text { SD } \\
\end{array}$} \\
\hline & & 1 & 2 & 3 & AV & 1 & 2 & 3 & AV & 1 & 2 & 3 & AV & \\
\hline 1 & pH & 7.30 & 7.55 & 7.68 & 7.50 & 7.10 & 7.33 & 7.48 & 7.30 & 7.45 & 7.60 & 7.65 & 7.60 & 7.46 \\
\hline 2 & $\mathrm{EC}(\boldsymbol{\mu S} / \mathbf{c m})$ & 0.21 & 0.24 & 0.25 & 0.23 & 0.28 & 0.28 & 0.27 & 0.27 & 0.21 & 0.23 & 0.24 & 0.22 & 0.24 \\
\hline 3 & Turbidity (NTU) & 3.98 & 4.20 & 3.98 & 3.5 & 3.80 & 4.00 & 3.78 & 3.86 & 3.95 & 4.00 & 4.10 & 4.00 & 3.78 \\
\hline 4 & $\begin{array}{c}\text { Alkalinity } \\
(\mathrm{mg} / \mathrm{L})\end{array}$ & 169 & 168 & 168.70 & 168.56 & 170 & 170.50 & 169.89 & 170.13 & 169 & 168.90 & 169.40 & 169.1 & 169.26 \\
\hline 5 & $\begin{array}{c}\text { Hardness } \\
(\mathrm{mg} / \mathrm{L})\end{array}$ & 3.98 & 4.20 & 4.10 & 4.09 & 4.00 & 3.80 & 3.90 & 3.90 & 4.10 & 3.90 & 4.00 & 4.05 & 4.01 \\
\hline 6 & Chloride (mg/L) & 23.00 & 22.89 & 22.50 & 22.00 & 21.60 & 20.90 & 20.70 & 21.00 & 19.10 & 18.80 & 18.90 & 19.00 & 20.06 \\
\hline 7 & Sulphate (mg/L) & 346 & 330 & 345 & 340.33 & 354 & 352 & 358 & 354.66 & 361 & 358 & 362 & 360.33 & 351.77 \\
\hline 8 & $\begin{array}{c}\text { Ammonia } \\
(\mathrm{mg} / \mathrm{L})\end{array}$ & 0.32 & 0.30 & 0.29 & 0.30 & 0.38 & 0.42 & 0.40 & 0.4 & 0.42 & 0.40 & 0.40 & 0.40 & 0.36 \\
\hline 9 & Nitrate $(\mathrm{mg} / \mathrm{L})$ & 38.20 & 38.40 & 38.30 & 38.30 & 38.77 & 39.80 & 38.75 & 39.10 & 38.50 & 37.80 & 37.50 & 38.20 & 38.50 \\
\hline 10 & Nitrite (mg/L) & 0.25 & 0.24 & 0.23 & 0.24 & 0.25 & 0.27 & 0.26 & 0.26 & 0.27 & 0.26 & 0.28 & 0.27 & 0.25 \\
\hline 11 & $\begin{array}{c}\text { Phosphorus } \\
(\mathrm{mg} / \mathrm{L})\end{array}$ & 0.58 & 0.59 & 0.57 & 0.58 & 0.57 & 0.56 & 0.58 & 0.57 & 0.57 & 0.58 & 0.55 & 0.56 & 0.57 \\
\hline 12 & Calcium $(\mathrm{mg} / \mathrm{L})$ & 3.30 & 3.00 & 3.50 & 3.26 & 3.20 & 3.30 & 3.10 & 3.20 & 2.70 & 3.10 & 2.89 & 2.89 & 3.11 \\
\hline 13 & $\begin{array}{c}\text { Magnesium } \\
(\mathrm{mg} / \mathrm{L})\end{array}$ & 2.70 & 2.60 & 2.50 & 2.60 & 2.60 & 2.40 & 2.55 & 2.51 & 2.80 & 2.90 & 3.20 & 2.96 & 2.69 \\
\hline 14 & Sodium $(\mathrm{mg} / \mathrm{L})$ & 2.60 & 2.70 & 2.89 & 2.73 & 2.90 & 3.11 & 3.30 & 3.10 & 3.20 & 3.10 & 3.18 & 3.16 & 2.99 \\
\hline 15 & $\begin{array}{c}\text { Carbonate } \\
(\mathrm{mg} / \mathrm{L})\end{array}$ & 9.80 & 9.90 & 10.20 & 9.98 & 10.10 & 10.25 & 10.20 & 10.10 & 9.80 & 9.90 & 10.00 & 9.95 & 10.01 \\
\hline 16 & $\begin{array}{c}\text { Bicarbonate } \\
(\mathrm{mg} / \mathrm{L})\end{array}$ & 34.90 & 34.60 & 33.70 & 34.40 & 34.20 & 34.30 & 34.40 & $\mathbf{3 4 . 3 0}$ & 34.10 & 34.00 & 34.05 & $\mathbf{3 4 . 0 5}$ & 34.25 \\
\hline 17 & BOD (mg/L) & 3.90 & 4.00 & 3.80 & 3.90 & 4.35 & 4.40 & 4.30 & 4.35 & 3.90 & 4.00 & 3.75 & 3.88 & 3.87 \\
\hline 18 & COD (mg/L) & 8.60 & 8.50 & 8.40 & 8.50 & 8.00 & 8.30 & 8.35 & 8.21 & 8.50 & 8.60 & 8.55 & 8.55 & 8.42 \\
\hline
\end{tabular}

$\mathrm{AV}$ - Average value SD- Solar Distillation 


\section{Phosphorous}

Phosphorus is an essential nutrient for the growth of organisms and helps for the primary productivity of a body of water. The presence of phosphate in large quantities in fresh waters indicates pollution through sewage and industrial wastes. Phosphorous was found with an average value $1.54 \mathrm{mg} / \mathrm{l}$ (Table 1). After the solar distillation the value of phosphorous was reduced and comes under the prescribed limit according to WHO water standards was $0.57 \mathrm{mg} / \mathrm{l}$ (Table 2).

\section{Biological Oxygen Demand (BOD)}

BOD indicates the oxygen content available for biological activity. The standard value required for BOD in water is 5 according to WHO (Table 3). BOD was ranging from $6.26 \mathrm{mg} / \mathrm{l}$ to $6.60 \mathrm{mg} / \mathrm{l}$ with an average value $6.39 \mathrm{mg} / \mathrm{l}$ in Sabarmati river water, before the solar distillation. After the solar distillation during condensation process BOD remains with an average value $3.87 \mathrm{mg} / \mathrm{l}$ due to inactiveness and sterilization of microbial diversity after the distillation process.

\section{Chemical Oxygen Demand (COD)}

COD value indicates the inorganic and organic contamination in Sabarmati river water. The COD concentration was found higher and above the prescribed level.COD was ranging from $15.26 \mathrm{mg} / \mathrm{l}$ to $20.56 \mathrm{mg} / \mathrm{l}$. After the solar distillation treatment the value reduced a raging from $8.00 \mathrm{mg} / \mathrm{l}$ to $8.55 \mathrm{mg} / \mathrm{l}$ with an average value $8.42 \mathrm{mg} / \mathrm{l}$ meeting to the standard of potable water use (Table 3).

\section{Turbidity}

Turbidity shows the suspended matters in the water. The value of turbidity was found 27.12 (NTU) which are above the prescribed limit by WHO (Table 3 ). After the solar distillation process the value reduced and found 3.78 (NTU) and suitable for potable water use. The solar distillation treatment was found a useful for turbidity reduction because of high temperature dissolved salt was settled down at the surface of basins. The river water is the source of water for various purposes such as industrial, agricultural, domestic and potable.

In the present study solar distillation a natural process has been designed and developed where in sun light in the form of radiation is captured on the top of solar distillation unit which heat the surface of solar distillation unit which heat the surface, incoming water is vaporized that itself remove the contaminants to certain extent. The vaporize water passing through three inbuilt basins in solar distillation unit following the incoming water interact at each stage of basin one by one for removal of contaminants. Further the condensation process also coalesce the contaminant and settle down on the bottom. The condensed water collected in a outlet collector. This process of treatment has reduced the parameters which were earlier found higher concentration now comply with the standards comply with WHO. Therefore solar distillation unit has been found effective and efficient, low cost and natural system for treatment of water.

\section{Conclusion}

Similarly the Sabarmati River at Subhash Bridge, Ahmadabad was collected and characterized for physicchemical parameters. This river water was found contaminant $\mathrm{pH}$, turbidity, ammonia, nitrate, nitrite, sulphate, BOD and COD above the permissible limit. After treatment this water can be used as potable water according to WHO and BIS water standards by using the Solar distillation unit via; Vaporization and condensation using triple basin system. The solar based technology can be applied in field for treatment of river water at particular source to remove the contaminant and make the water suitable for intended use. Solar unit has been found effective, efficient and low cost technology for distillation and treatment of contaminant water. Further study using biotechnological and nanobased material as a catalyst would improve the treatment and can be transferred from lab to land for water and waste water treatment.

\section{Acknowledgement}

The research work has been carried out for master of philosophy supported by Central University of Gujarat both financially and technically. I am also highly indebated to Prof. M. H. Fulekar (Dean, School of Environment and Sustainable Development, Central University of Gujarat Gandhinagar) forgiving permission to carry out my research work. I am very thankful for his

Moral support and guidance, his encouragement. Profound gratitude tomy Supervisor Dr. Bhawna Pathak (Associate Professor, School of Environment and Sustainable Development, Central University of Gujarat 
Gandhinagar. And my lab mates, their day and night care is always admirable.

\section{References}

APHA, AWWA, WEF (2012). "Standard Methods for examination of water and waste water". $22^{\text {nd }}$ ed. Washington: American Public Health Association; 1360 pp. ISBN 978-087553-013-0.

Carter F. W. (1985). "Pollution Problems in Post-War Czechoslovakia", Transaction of the

Institute of British Geographers, 10(1): 17-44.

European Public Health Alliance, (2009). Air, Water Pollution and Health Effects.

Fulekar M. H., Pathak B. and Kale R. K. (2014). "Environment and Sustainable Development". Springer, DOI 10.1007/978-81-322-1162-2, SBN 978-81-322-1166-2

Gandhi T. K. (2013). "Water chemistry: A study of dissolved heavy metals in Sabarmati River,

Gujarat, India”. Global Research Analysis, 2(5): 22778160.

Hugh C. and Madauka C. (2005). "Water pollution and man's health". Int. J. Gastroenterl, 4(1): 151-159.

OlaniranN.S. (1995). "Environment and Health: An Introduction", Olaniran, N.S. etal (Ed)

\section{How to cite this article:}

Anuradha Awasthi, Bhawana Pathak and Fulekar, M.H. 2017. Solar Distillation an Advance Treatment for Decontamination of River Water. Int.J.Curr.Res.Aca.Rev. 5(2), 63-70.

doi: http://dx.doi.org/10.20546/ijcrar.2017.502.009
Panchal H., Patel N. and Thakkar H. (2015). "Various techniques for improvement in distillate output from active solar still:a review". International Journal of Ambient Energy. http://dx.doi.org/10.1080/01430750.1076518.

Raju V. R. and Narayana R. L., (2015). "Effect of Flat plate collectors in serious on performance of active solar still for Indian coastal climatic condition". Journal of King saudUniversirtyEngineering sciences.

SiddiqquiM. T., Satyapal and Jain A. (2015). "Analysis of Solar Still with Reflector". InternatinalJournalk of technology Research and Engineering, 2(7). ISSN 2347-4718.

SobhaB.S., Watwe V., and Rajesh A.M. (2012). "Performance Evaluation of a Solar Still Couples to an Evacuated Tube Collector type Solar Water Heater". International Journal in Engineering and Technology, 1: 2319-1058.

Turner R.K., Adger W.N. and Lorenzoni I. (1998). "Toward integrated modeling and analysis in coastel zones: principle and practices". LOICZ report and studies, 11:182-196. 